\title{
CrimRxiv
}

\section{Eroticization of the body, reflexivity, and qualitative methodology in criminology: An Omerta}

Catherine Montmagny Grenier

Published on: Jun 10, 2021

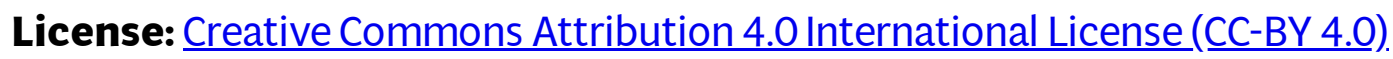




\section{Abstract:}

This article reflects upon the notion of reflexivity in qualitative methodology, both generally, and specifically within the field of criminology. This reflection stems from the completion of my pre-field research in Costa Rica, which I undertook during the realization of my doctoral thesis regarding the sexuality of solo female travelers. Based on a sexual assault I experienced during this pre-field research, I critically discuss the notion of reflexivity in cases where the security of researchers is undermined by the relations of power that exist between gatekeepers and participants as a result of gender identity and the eroticization of the body. This article specifically questions the space assigned to researchers and their bodies in the reflexive process that occurs during fieldwork.

We were allowed to play with their words, their ideas, their culture as long as we

pretended we were men. As soon as our cunts bobbed into the light of day, they stiffened, their lips tautened, they seemed to draw themselves into themselves; they cut us down. It was better not to try. One part of ourselves mocked another. We joined in their ridicule of our own aspirations. Either you played their game or you didn't play

at all. (Rowbotham 1973: 30)

\section{Introduction}

I take the liberty of undertaking this conversation in order to interrogate a form of negation that occurs related to the erotic subjectivities that are attributed to researchers during the reflexive process in qualitative research, as understood Sandra Harding (1991), and Gillian Rose (1997). This reflection is based on the recent accounts of other ethnographers from outside the field of criminology, who experienced sexual violence in the course of their fieldwork. Their stories led me to the realization that my own experience of sexual violence while undertaking fieldwork was not unique. Rather, it resulted from a form of taboo. The discussion regarding erotic subjectivities was introduced over twenty years ago by a smattering of voices, particularly in anthropology (Bell et al. 1993; Kulick and Wilson 1995) and feminist geography (Bell and Valentine 1995; Duncan 1996). This interrogation remains relevant, even essential. New voices have continued this conversation within these disciplines (De Graeve and De Craene 2019), as well as in sociology (Clair 2016; Hanson and Richard 2019), highlighting two issues, which are at once different in 
nature, and intimately linked. I intend to (re)open this discussion in regard to the field of criminology, as these issues also affect the discipline and its ethnographers.

Over 25 years ago, Elizabeth Stanko (1992) studied the negotiation of criminology researchers' sexuality. In surveying members of the American Society of Criminology, Stanko showed that over $30 \%$ of respondents had experienced at least one episode of sexual harassment during the course of their fieldwork, and that this had had a significant impact on their research process, particularly in the case of female researchers. Furthermore, she highlighted the fact that these incidents of sexual harassment, in some cases assaults, were committed not only by research participants, but also by gatekeepers providing access to the research field, as well as by coresearchers. Stanko also pointed out that none of her survey's female respondents had made mention of these incidents, in any way. As such, Omerta appears to be the rule. Stanko's article-intended as a pilot project-appears to have been abandoned. In line with the \#MeToo movement, I seek to restart such a discussion by further reflecting on the reflexive processes in qualitative methodology, which is presently strongly rooted within criminological research. Specifically, I intend to show that the reflexive process is incomplete, as it simultaneously fails to take into account researchers' erotic subjectivities with regard to their bodies, the eroticization of these bodies by other research actors, and the power relations present between researchers and these actors. I argue that these shortcomings encourage and maintain a form of taboo which, on the one hand, hinders the production of positioned and situated knowledge and, on the other hand, encourages a form of gendered violence against female researchers.

However, prior to questioning this negation of erotic subjectivities within the context of the reflexive process, it is important to first define the notion of reflexivity as it relates to qualitative criminological research methodology, as well as to understand its current application.

\section{Reflexivity: the recognition of relations of power in the research process}

Within the field of criminology, the notion of reflexivity has for many years been a part of the qualitative research methodology. This notion stems principally from the work of critical criminologists (notably Jock Young in the 1970s and 1980s) and the significant influence of the second Chicago school and its interactionist perspective (see Poupart 2011 , for a summary of this influence). Criminology is the social science discipline that most dangerously waltzes with power: the criminal and deviant categories, classifications, labels, and images produced by criminological knowledge are both stigmatizing and pejorative. 
This emergence and progression of critical criminologists' work had the effect of aggressively interrogating the dominant position held by positivist and normative criminology. Subsequently, works by feminist criminologists (Gelsthorpe and Morris 1990; Kleinman 1991) made it apparent that subjectivity was actually one of qualitative methodology's strengths. Defined as a reflexive space related to representation of the self, subjectivity accounts for the researcher's awareness of their representations and relations with the world (Bertucci 2009). In wanting to give voice first to women, then to marginalized populations, feminist and critical criminologists took into account in their analyses the influence that they themselves had on the research process. Specifically, they recognized that "narratives are constituted in situ, and are necessarily products of relational processes occurring in circuits of social power between researchers and participants," (Panfil and Miler 2015: 54). As such, these criminologists shed light on the relations of power present within the researcherparticipant relationship that resulted from a conjunction of identities. For example, in relation to gender, sexuality, ethnicity, social class, social status, and ableism. This form of recognition, arrived at via the reflexive process, particularly during participant observations and the conducting of interviews, fully makes room for both the participants and the manner in which they construct their narrative. Reflexivity avoids both tarnishing the discourse regarding, or speaking in lieu of, anyone, while at the same time highlighting the problematic nature of the reifying veneer of an externally conceived theoretical framework. Thus, in this vein, the notion of reflexivity refers to an analysis of the relations of power present in the established relationship between researcher and participant. It depicts the research process as one involving respectful and consensual negotiations between various research actors (Bertucci 2009).

\section{Undertaking fieldwork: from difference to otherness}

Criminology has been influenced by an epistemological reflection regarding otherness first developed in the field of anthropology. In fact, becoming aware of both our identity as researchers, and the associated consequences on the research process, is first and foremost a part of Lévis-Strauss's (1968) vision of the object. To him, our subject is also an object: "[a]ny society different from ours is an object; any group in our own society, other than the one to which we belong, is an object; any use of this very group, to which we do not belong, is an object," (Lévis-Strauss 1968: XXIX, my translation). As such, shedding light on the subjectivity of researchers by highlighting the differences that separate them from their participants in turn gives way to the desired form of objectivity (Bertucci 2009). However, reducing otherness to a simple difference is not a matter of knowledge (of oneself), but rather the logical function of 
reason. The observer is not changed by the difference. Instead, otherness, a dimension of exotic consciousness that seeks to embrace that which is distant, implies abandoning reference points (Affergan 1987). In summary, the anthropological approach aims via a dual process to understand others as an otherness, while at the same time understanding one's self to be an other, both within a reciprocal relationship and via an interactional process. In this way, the anthropologist can admit to being changed by others, which is not without stakes or consequences when it comes to the production of social science knowledge (Affergan 1987; Bertucci 2009).

By opting to employ an active voice, researchers engage in a form of reflexivity that takes into account their agency within the research process. They recognize that resulting knowledge is based on a research process co-constructed by various actors. In addition, the emotions researchers experience are now taken into account in this process of qualitative social science research. That researchers are affected by the research field they are studying is acknowledged (see in particular the work of Jeanne Favret-Saada 2004, 2009), particularly within criminology (Campbell 2002; Kleinman 1991; Wesely 2015).

In a similar vein, cultural criminologists' work pushed the reflexive process forward by taking into account actors' emotions, as well as their construction of meaning during fieldwork (Ferrel and Hamm 1998; Kane 2004; Kleinman 1991). Cultural criminology is characterized primarily by its use of ethnography as a research methodology (Hayward 2016; Kane 2004; Young and Brotherton 2014). Cultural criminologists may therefore encounter a certain degree of vulnerability when conducting their fieldwork, due to finding themselves in different, minimally familiar, completely unknown, and even dangerous contexts (see Jacobs 2011, for examples). As a result, depersonalizing the remarks and observations reported during the undertaking of fieldwork, by subtracting the ethnographer's own experience, undermines the desired goal of scientific objectivity. As such, cultural criminology invites ethnographers to employ an attentive gaze (Hayward and Young 2004), or an ethnographic sensibility derived from criminological verstehen (Ferrell and Hamm 1998). This concept takes the form of a personal effort in which the researcher engages reflexively not only with the participants, but also the situations in which the research occurs and is carried out. Thus, reflexive cultural criminology takes into account not only the relations of power between researcher and participant, but also researchers' emotions and physical bodies (see among others Monaghan 2011, for an overview of the literature), the environment in which the research occurs (Hayward 2016; Kane 2004), and the taking of risk (Lyng 2014). 
Qualitative methodology in criminology, specifically the ethnographic method, produces situated and positioned knowledge by following an approach similar to that proposed by Francis Afferghan (1987). Through the achieved reflexivity, places, participants, and researchers (via their emotions and bodies during the ethnographic experience) are fully accounted for in the production of knowledge. An autoethnography, understood as "a form of ethnographic enquiry that maintains a strong focus upon the researcher's biographic and emotive self" (Wakeman 2014: 705), should also be undertaken to illustrate the ways in which any biographical congruence between participants and the researcher's (emotional) self (as well as the body within which it is inscribed) impacted the practice of ethnography, the engendered data, and ultimately, how this data was presented (Jewkes 2011; Root, Ferrell and Palacios 2013; Wakeman 2014). Taken together, is this reflexive process complete? Are all the components involved with the undertaking of an ethnography currently accounted for in cultural criminology?

I propose the thesis that this reflexive process is in fact currently incomplete. While it does account for the researcher's body, the sexuality attributed to it is essentialized to sexual orientation, and either confined to the topic of the researcher's choice of clothing (Bucerius 2013), mentioned in the form of sexual tensions that are perceived as an ambient risk for fieldwork (Lee 1995), or simply ignored. Such negations are present even in certain canonical criminological texts' analyses. Howard Becker (1963) appeared to tell readers that his research for Outsiders took place in a dance club, when it was in reality a strip club. In addition, it would appear that the relations of power present between researchers and gatekeepers, as well as with other research actors, are only considered through the lens of opportunities for gaining access to field research sites and participants (Fitz-Gibbon 2017). By contrast, I argue that relations of power also shape the relationships between researchers and gatekeepers, and that gatekeepers exercise a great degree of influence on the research process. Thus, I argue that the essentialization, or even negation, of these additional components is detrimental to the production of situated and positioned knowledge, and can in addition thrust novice researchers into a vulnerable or even dangerous situation while conducting fieldwork.

I will support the presentation of this thesis by sharing my personal experience of having my body eroticized by my gatekeeper in the course of realizing my doctoral thesis pre-field research. In seeking to contribute specifically to the development of cultural criminology, the presentation will take the form of a dense description, as understood by Clifford Geertz (1998), (Ferrel and Hamm 1998; Yong and Brotherton 
2014). This approach is useful for bringing the reader into the world of the ethnographer and helping them understand the thesis being advanced (Denzin 1989). Specifically, I seek to illustrate the way in which the negation of my own sexuality led to a confusion in the degree of interpretation between thickdescription and thin description, with respect to my gatekeeper's actions (Ponterotto 2006). I will discuss this confusion by viewing my pre-field research as a passage into a liminal space in which I assigned myself a place (Favret-Saada 2009). Lastly, I will discuss the concept of sexuality in the field of criminology in order to explore why it is currently absent from ethnographers' reflexive process, as well as why it is both relevant and worthy of inclusion.

\section{Where are the gendered and sexualized bodies?}

Ignoring researchers' sexuality, and more specifically their erotic subjectivities, results in a pair of significant issues. The first of these is of a methodological nature. Research is a process that results from interaction between the researcher, participants, and the research environment (Rose 1997). As such, essentializing sexuality to sexual orientation, or focusing solely on the erotic subjectivities attributed to researchers, as is generally the case in the social sciences (Clair 2016), biases the knowledge that is produced. The reflexivity is not completely transparent, as both the researcher's sexuality and the erotic subjectivities surrounding them are excluded from analysis (Cupples 2002). What contributes to sexuality and erotization being so taboo? Certainly, institutional research ethics propagate the illusion that undertaking research without either affecting or being affected by the research field (and the individuals therein) is both essential and possible. It is equally clear that a researcher discussing their sexual(ized) interactions and bodily feelings within the research context can potentially jeopardize their respectability (De Graeve and De Craene 2019). However, as noted above, cultural criminology encourages employing an autoethnographic analysis that addresses emotions such as fear, empathy, and experienced physical violence (Jewkes 2011; Wakeman 2014). Why then are sexuality and erotic subjectivities excluded?

A researcher's body is not devoid of erotic subjectivities once arrived at the field research site. As such, these subjectivities should be acknowledged and addressed (Clair 2016). Any attempt to deny or even diminish their impact on research is useless, as we are still sexually positioned by our participants, as well as by other actors directly or indirectly partaking in the process (Clair 2016; Cupples 2002; Hanson and Richards 2019). This last point is of great importance, because it "[...] affirms feminist 
scholars that reflexivity is not simply about researchers themselves, but also about how we are seen by the people we do research with and the relations of power within these contexts," (de Craene 2017: 451). The absence of sexuality contravenes the reflexivity process. It renders invisible the eroticization to which the researcher may be subject to. Such negation also has important consequences for the production of situated and positioned knowledge. Case in point, how can the act of being hit on or even assaulted be viewed as having no effect on researchers' subjectivity and the research process itself (Clair 2016)?

The scientific literature's negation of the researcher's erotic subjectivities, and more precisely of the eroticization and sexualization of their body, also raises a political issue. One the one hand, it creates the impression that the "researcher" status provides immunity against a certain degree of eroticization while conducting an ethnography. On the other hand, it undermines fully informed fieldwork preparation for novice researchers, potentially resulting in them finding themselves in vulnerable, or even dangerous situations. This is because the reality of fieldwork differs greatly from any supposedly granted immunity. Numerous ethnographers, belonging to a wide range of social science disciplines, have in fact been assaulted (to varying degrees) during the undertaking of their fieldwork. Negating researchers' erotic subjectivities has the effect of implying that these unfortunate incidents are simply isolated cases. This negation also discredits female researchers' professionalism (Clark and Grant 2015; Moreno 1995; Stanko 1992), while equally trivializing and (re)producing gendered violence (Hanson and Richards 2019).

With the aim of responding to the methodological and political challenges mentioned above, I will share my personal experience of having my body eroticized, which occurred during the realization of my doctoral thesis pre-field research. While sharing this experience is certainly uncomfortable and difficult, given that it is an incidence of sexual assault, it is nonetheless relevant (Taylor Sanchez and O'Connel Davidson 2010). The goal of this sharing is not to in any way dissuade ethnographic research from being carried out, and even less to show that it is (more) dangerous for females to undertake fieldwork-this type of incident can occur even in the course of our everyday lives. I do, however, feel that undertaking fieldwork locates researchers in a context of vulnerability that can, in a way, facilitate this type of event. Thus, I share this episode in order to highlight a reality shared by numerous female ethnographers, as well as its impact on the research process (see Clark and Grant 2015). This sharing also interrogates the notion of sexuality in qualitative methodology within the field of criminology, specifically during the undertaking of ethnography. It also sensitizes 
novice researchers to the eroticization of their bodies by gatekeepers or colleagues during the undertaking of fieldwork, in order to improve their preparation.

\section{Liminality, or learning in the field}

Taking inspiration from Victor Turner's (1979) rite of passage concept, I approach my fieldwork experience as a liminal phase, one in which I was a passenger (Clark and Grant 2015; Plump and Geist-Martin 2013). First, I left my ivory tower and headed to my field research site, thereby creating a stage of separation with my previous statuses. Second, I entered the liminal phase, that is, a nebulous period where the features of both the past and the future are absent, corresponding to the undertaking of fieldwork. Third, and finally, I re-incorporated into my everyday life, having learned and evolved via my experience, as well as having been affected and changed by it. Qualitative methodology's reflexivity process makes possible this re-incorporation (Favret-Saada 2009; Hert 2014).

The elapsed time and distance since the fieldwork experience makes it possible to construct a bridge spanning the past to the present. Like Jacob Climo (1999), I conceive of the field research site as a liminal social space strongly characterized by ambiguity, contradictions, and individual isolation. This space thus implies "a breakdown of cognitive schematic frameworks; an absence of status, anonymity, sexual continence, or excess; loss of a sense of self and identity; emotional pressure, and collapse; the stripping of ego defense and a heightened sense of vulnerability and suggestibility; [...] and a willingness to accept pain and suffering and be unselfish, humble, and obedient," (Climo 1999: 45). This space is also shaped by the time, and economic and human resources, that are allocated to carrying out the research project. Thus, this space locates researchers, considered here to be passengers, in an in-between space where a desire for autonomy and a dependence on others (i.e., participants, key informants, gatekeepers) continually pulls them in opposing directions (Hert 2014; Moreno 1995; Kloß 2017). In short, this field research site differs significantly from our everyday life.

In addition, I argue that viewing this field research site as a liminal space highlights researchers' bodily experience, and this, without the field being qualified as dangerous (Hert 2014). To be present at the field research site is to agree to participate and be affected. That is, to be altered by the experience (Favret-Saada 2009). As such, before describing the incident in question, which will guide the interrogation of the erotic subjectivities attributed to researchers, it is important to first place it into context. 


\section{You do not do fieldwork, fieldwork does you}

The incident in question occurred during my doctoral thesis pre-field research in December 2015. I had been staying at a youth hostel for over three weeks in a town on Costa Rica's Caribbean coast. I was seeking to study female tourists' libertine sexualities. As such, I spent my weeks wandering around the small community in order to observe both how female tourists generally behaved during the day and at night, as well as their interactions with local men. I also conducted interviews with an eye towards identifying the most sensitive and taboo subjects and themes to address.

From the beginning of this sojourn, I identified myself as a researcher, without feeling any embarrassment in regard to discussing my research topic. I was well received, even if I did pique certain individuals' curiosity. Case in point, Johel, $\underline{1}$ a 21 -year-old local male working at the hostel, seemed not to understand what I was doing. Why was I spending entire days at the hostel on my computer, and why did I appear so anxious to find local contacts? Once I explained the reason for my presence, Johel generously offered to assist me, thereby becoming my gatekeeper. He accompanied me over several evenings at local bars, putting me in touch with friends of his who were presently having (or had had) intimate and sexual relationships with white western female tourists. He would introduce me as the investigadora del sexo, which would make his friends, as well as myself, laugh, because that was really what I was: a researcher studying sexuality.

Over days spent discussing anything and everything, Johel confided to me that he'd had dalliances with several hostel clients, and that he was currently in a relationship with a French woman. Being a Francophone myself, he asked me if it was true that Francophone women were more inclined towards oral sex than other women.

Laughing, I answered that I didn't know, but that I found this prejudice very interesting. He also laughed and returned to his chores at the hostel. Then, before leaving to head home, he invited me to join him the following morning for the picking of bananas for customers' breakfasts. Before accepting, I asked him if he could also possibly show me his small cannabis plantation. Johel was a supplier for the hostel's customers, which brought him a not insignificant income. The criminologist in me was curious. He smiled proudly without saying a word. He did, however, ask me to keep the following day's expedition a secret.

The following sentences are difficult and describe the incident in question. They are verbatim excerpts taken from a notebook. I had not written about this episode in my 
official field journal, but rather in a small notebook containing grocery lists and other scribblings, the night after the event:

Everyone at the hostel was asleep except for me. It was 6:30 in the morning and I was awaiting Johel, who was picking me up to for banana picking in the mountains in order to supply fruit for the hostel guests' breakfasts.

The hum of the motorcycle's engine could softly be heard between the howler monkeys' cries. I descended from the hostel's terrace to join Johel at the terrain entrance. Sporting a t-shirt, Bermuda shorts, rubber rain boots, and a machete in his hand, he greeted me with a big smile and beckoned me to take a seat behind him. "Are you ready for adventure? You'll see, it's really beautiful! I hope there'll be toucans. There are usually a lot of them in the morning. I'll show you their little corner!" he said to me in a highly cheerful tone. "YES, I'm ready," I replied, taking a seat behind him, and placing my hands on his shoulders to keep my balance. We then left [...].

During our ascent, Johel explained to me the difference between plantains and the bananas we were going to pick. We paused to observe a sloth that appeared to be nothing more than a grey-green stain at the top of the tree. After setting out on the road again, I noted to myself that Johel was more attuned than me to his environment, which in my case, only filled me with wonder. The stimuli were far too numerous for me to remain focused on a single one of my senses: the range of greens flashing before my eyes; the various bird songs, mixed with the cries of the howler monkeys, as well as the motorcycle, which seemed to lag behind; the lingering smell of moisture, wet earth, and flora; and the still bearable heat weighing down on my skin, causing beads of sweat to form on my wrists. I was pulled away from my thoughts when the motorcycle came to a stop. Johel informed me that we had to leave the motorcycle behind and continue our quest on foot for about ten minutes [...].

Holding the machete between his teeth, he climbed towards the mountain's summit in order to cut down banana bunches. With the bananas now on the ground, he greeted me from on high before nonchalantly descending. He then asked me if I was feeling hot, and if I wanted to go swimming. In response to my questioning glance, he told me that there was a river nearby, that we had the time, and that it would clear my thoughts, and allow me to better work on my thesis. I signaled that I would follow him, since after all, he was in charge of the hostel's breakfast, and I really was feeling hot. I let Johel pass in front of me, so that he could guide me to the river. Johel stopped in front of a muddy pond and handed me his machete: "Grab it, and I'll carry you in my arms to get across the mud." Surprised, I answered that he didn't need to do that, and 
that, like a big girl, I was going to cross the mud pond alone without even dropping the bananas. He insisted, noting that he had rubber boots on, while I was wearing nice hiking shoes. Johel stepped towards me and lifted me up in his arms like a baby. Caught off guard in this position, I struggled a little, repeating with a nervous laugh that my shoes were made to be dirtied, and that I really could walk. He brusquely put me down, took the machete from my hands, and stepped back in front of me. I silently followed behind him towards the river, without really understanding what was happening. After about five minutes, we arrived.

Johel was once more cheerful. He placed his machete on the ground, and quickly removed his shirt and boots, before immersing himself in the clear water. Charmed by the landscape, I put the bananas down, searched my bag for my cell phone, and snapped a few pictures. I then put my bag down, removed my shoes and socks, and entered the river. The water was cool and came up to my waist. Johel asked me why I hadn't removed my shorts. I told him that I didn't have a swimsuit bottom with me, only my panties. [...] Johel again insisted that I take off my shorts, to which I replied, in a drier tone: "NO! It's my butt and I decide who I show it to. That's it. I won't take my shorts off." He then became more assertive, and even aggressive: "YOU WILL TAKE THOSE SHORTS OFF." I froze at the force of his voice, stunned. He pulled my shorts down and pushed me back. He then took the opportunity to grab my leg and remove the shorts. Frightened, I removed my other foot from the shorts and handed them to him. He accepted them with a smile and threw them to the other end of the bank. I began walking in the opposite direction towards my backpack. Johel shouted: "Where do you think you're going? Come back. We're going swimming!" I hesitated, but something clicked for me when my eyes fell upon my backpack and Johel's personal belongings. A combination of factors flashed through my mind, and then a conclusion: the absence of a cellular network, which I had curiously noted while taking pictures, and the machete. I wasn't going to win. He was stronger than me on multiple levels. First, I couldn't physically fight him, as I would certainly get hurt. He had the machete. Second, even if I wounded or knocked him out, I didn't know where I was geographically located within the jungle, and without cellular reception, I was lost, on top of nobody at the hostel knowing that I had left with Johel. I shifted into survival mode. I turned to join him in the water and told myself that I should avoid upsetting him.

[...] Johel approached me and asked me to take him into my arms and hug him, under the pretext that he was cold. I didn't move. He then took my arms, placed them around his neck and put me on my feet. We were face to face, standing with our bodies glued 
together, my arms around his neck, and his hands on my buttocks. Johel was kissing my neck. I tried to push him away gently, but he would only squeeze me tighter. "Aren't you tempted? Am I not having any effect on you?" he asked me. "No. I'm completely indifferent to you." "Don't you want to have sex with me? Don't you like me?" he asked in an angry voice, gripping my wrist. A thought came to me: "OK. I need to buy some time. I need to reduce my risk of injury. The machete."

I was thinking quickly, searching for another excuse for refusing his unwanted advances, one that wouldn't upset him. "Johel, you're the same age as my little brother.. you're like my little brother," I told him calmly, in a tone intended to come off as slightly warm. "I'm not your little brother!" he curtly responded. "I know. What I mean is that you're as young as him, and in my opinion there's a barrier," I said. He again grabbed me by the wrists and pulled me closer, against him. He whispered in my ear in a cold tone that he didn't care, that I wouldn't be the first thirty-year-old woman he had sex with. I froze on the spot. "No seras la primera. He's speaking in the future tense. So, he will have sex with me," I concluded. "Put your clothes back on. I'll show you my secret hiding place. I'll show you where I grow my ganja plants." He ran out of the water, grabbed his shirt to wipe himself dry, put on his boots, took his machete in one hand, and the bananas in the other. "Come on, come on! Hurry up! We don't have all day!"

With his left hand firmly grasping my right hand, Johel dragged me behind him. My eyes ignored the landscape, fixating only on the machete in his right hand. We were in front of a wooden house mounted on stakes. We climbed up on the gallery and Johel showed me where he grew his ganja plants. I congratulated him with a smile, though I was shaking with fear on the inside. He was proud. He took me by the arm in order to pin me between him and the gallery ramp. He kissed me, his tongue in my mouth. I remained frozen. "I'm having no effect on you?" he again asked. "No, " I calmly answered. Nothing is going to happen between us, Johel." [...]

He suddenly lifted me off the ground, took me in his arms, and brought me into the house. He violently put me down on a bed without bedding in the middle of a large room, which seemed to be the only one in the house. He straddled me, in order to restrain me on my back, while pinning my wrists above my head with one of his hands. He placed the machete next to the left side of my face and began undressing me. At that point, I told myself that I was going to be raped. I stared at the machete and "accepted" the situation. My mind disconnected: his hands and lips were running up and down my body, but I felt nothing. Time passed. 
Johel suddenly stood up and grabbed his machete. He shouted at me, "Get up! Grab the bananas. We're heading back to the hostel." I came to my senses. I visually scanned my body. I was partially clothed and without injury. Sexually assaulted, but alive, and not raped. [...] We silently returned to the motorcycle. Johel beckoned me with the machete to take a seat behind him. When the motorcycle finally came to a stop, Johel told me to get off and return to the hostel. I stood up quietly, still hugging the bananas in my arms. I looked him in the eyes and asked, "Was all this planned? Did you bring me to the mountain just to have sex with me?" To which he arrogantly answered: "Definitely not just for banana picking, you idiot!"

It should be understood that this event personally marked me, in addition to influencing and even reshaping my thesis research process.

\section{Re-incorporation: returning from the field research site}

It was while rereading my field notes in order to adopt a reflexive stance vis-à-vis the data I was collecting, with a view towards situating the knowledge I was producing (Harding 1991; Rose 1997), that the above-described episode surfaced. I had not forgotten about it, but had instead pushed it aside, or rather, sublimated it, in the course of my fieldwork. It's my belief that the shame of having experienced this event, or at least of not having seen it coming; the fear of losing access to my field research site, and having to start all over again when my time and financial resources were limited; combined with the fear of having failed in my fieldwork, or of not being a good enough ethnographer, made it so that the sublimation of this event was the best available option that would allow me to continue my research (see Clair 2016; Clark and Grant 2015; Moreno 1995; Stanko 1992; Kloß 2017 who shared these same emotions and fears following their experiences of eroticization, and even assault, in the field).

That being said, to sublimate is not to erase. This event marked me, affected me, and thus upended my research process: to a certain degree, I avoided local males during my fieldwork. By limiting my contact with them, I cut myself off from additional gatekeepers who might have helped put me in touch with my target demographic. I had entered the research field to understand female tourists' libertine sexualities. I sought to identify the motivations and relations of power that underpin the sexuality shared between western female tourists and local Costa Rican males. However, of the 27 interviewed participants, only three had had sexual relations with a local male. These results contrast with those of Susan Frohlick (2013), whose studies have focused on female tourists' sexuality, and with whom I shared a common field research 
site. During her fieldwork, she conducted interviews with western women who had had sex with local males. This was also something I sought to do, but was not really able to accomplish. For a long time, up until recently, I explained this discrepancy as resulting from the age of the participants. Today, I understand that my entire body produces knowledge. As Philippe Hert (2014) argues, drawing on the words of Jeanne FavretSaada (2004: 30, our translation) "before becoming aware of it, the ethnographer is affected by the place they are studying. This allows them, after the fact, to understand what occurred as a result of the game of places they were caught up in."

In addition to my acquired after-the-fact awareness, I for a long time wondered how such an incident could have happened to me: How could I have failed to see it coming? Am I that stupid?

\section{A body in the research field first, and only after a researcher}

I do not believe that I entered the research field unprepared. It being my first fieldwork experience, I had read up on the ethnographic approach and method (Beaud and Weber 2010); on Costa Rica; about the possible risks and dangers of conducting an ethnography (Lee-Treweek and Linkogle 2002); and more specifically, about deviance (Brougham 2012) and the sexuality of female tourists (Frohlick and Harrison 2008); as well as about the possible difficulties, risks, and dangers of being a researcher alone in the field (Bell et al. 1993). I also informed myself regarding the possible impact that the conjunction of my identities (status, class, gender, ethnicity, age, and sexual orientation) could have on the conducting of my interviews with both female tourists and local men (Frohlick 2013). I at least felt ready to minimize these risks. I headed out from my ivory tower prepared. However, it never occurred to me that I would be sexually assaulted by my gatekeeper, just as Karen Ross (2013) was. Likewise, Sinah Theres Kloß (2017), never suspected that her adoptive father during her anthropological fieldwork would sexually harass her, nor did Eva Moreno (1995) ever suspect that she was going to be raped by the research assistant she'd hired for her fieldwork.

What we have in common is that we did not envisage being eroticized, or sexualized, during our fieldwork by people other than our participants. We disregarded the other actors partaking in the research process. It would be possible to excuse my female colleagues by the fact that their research topic, contrary to mine, was far removed from sexuality. That being said, Valerie de Craene (2017), while researching the geography of sexualities and precisely the influence of heteronormativities on the performance of gender and sexuality in the context of student nightlife, was also 
surprised, even shocked, when she was sexualized via a comment her research director made. Similarly, Jennifer Wesely (2015) was caught off guard when young men inappropriately approached her with sexually suggestive comments while she was waiting for one of her participants outside their workplace, an exotic dance bar. She specifies: "Written the morning after, my notes demonstrate my raw reactions to what happened. I had directly connected the stripper identity to assault, suggesting that if the men had known me, known I was a non-stripper-I would never have experienced this," (2015: 151).

In my case, I had employed my researcher status as a chastity belt, much as my female colleagues seem also to have done. I thought that my identity as a researcher pushed my other identities into the background: I was a researcher, not a cisgender, heterosexual, white woman in her thirties traveling solo. I was a researcher, I was a professional, and so I had to be nonsexualized. I was unlike my participants; I was not a tourist imbued with sexuality. I thus modulated the conjunction of my identities in order to adapt to my time in the liminal space, as well as to dissociate from my participants (Plump and Geist-Martin 2013), with the goal of distinguishing myself from them in the eyes of additional actors involved in the fieldwork (Clair 2016). Because I shared a common conjunction of identities with the majority of my research participants, I viewed my unexpressed sexuality as a disciplinary barrier that would delineate my fieldwork. This modulation of my identities, in order to perform my status as a nonsexualized researcher, occurred naturally. I positioned myself as such by assigning myself this place in the space that represented my field research site. This positioning corresponds with what is found in the academic literature, or rather what is advocated for, in a certain way, by the classical canons of ethnography. The negation of sexuality distances the ethnographer from their participants (Clair 2016; Clark and Grant 2015; Kulick and Wilson 1995).

That being said, we cannot be the ones to choose which space is attributed to us in the research field. The field research site is a liminal space. Although an in-between space for researchers, it nonetheless remains the respondents' and gatekeepers' everyday reality. Therefore, one must accept to get lost in it. As Jeanne Favret-Saada (2004: 8, my translation), argues:

"Ethnographic work consists in deliberately attaching oneself to a system of places unknown to us: the one particular to the group we have chosen to study. As such, 'occupying a place' [...] consists rather in not aiming for any specific place, not even that of an ethnologist. I had to accept being there, being present, and 
that's it. And to let people assign me a place that appears suitable to them, or a different one-depending on the moment and the interlocutor. [...] What is called "work" in the field therefore involves moments of great passivity, wherein one is not in control of various situations. The Other plays a game whose rules are unknown to us, it suffices for us be flexible."

Thus, in viewing myself as a nonsexualized researcher, I assigned myself that place in the research field, which resulted in me rejecting the place assigned to me by Johel, my local gatekeeper.

It should also be noted that our body is not one from which we can subtract or add an identity depending on the situation we find ourselves in. Our body allows us to experience the world. It can thus be a source of tension when our representations fail to match our experiences (Hert 2014). In my case, although I left my ivory tower as a nonsexualized professional researcher, in the field I was not at first glance identified as such. I was identified as just another white western francophone tourist traveling solo. As such, even if refused to perform my sexuality, my body's erotic subjectivities were not erased upon reaching the field research site. The place Johel assigned me was that of all the other solo white female travellers.

It is the rejection of this assigned place, engendered by a negation of my sexuality, that created a discrepancy in the degree of interpretation regarding Johel's gestures. In clinging to my status as a researcher and believing that it rendered me nonsexualized, an error crept into the degree of interpretation. My position in the field as a nonsexualized researcher resulted in my casting aside the social codes associated with certain gestures. This, despite the fact that I had been watching Johel and his friends hitting on females in bars for over 20 nights. As such, I witnessed Johel's actions towards me, but failed to detect the flirting underlying them, positioning myself as a nonsexualized researcher. I heard, but did not listen to Johel's comments, particularly regarding the link between francophone women and oral sex. I found this comment interesting vis-à-vis my research, but I never thought it could be applied to me, similarly to how my female colleagues Jennifer Wesely (2016) and Sinah Theres Kloß (2017) ignored certain comments or signs made in their direction as both women and eroticized bodies in a given space and time. By assigning myself a place, I completely ignored who I was within this liminal space, as had my female colleagues.

It was only during the incident that I again became aware of my sexualized body. I became aware of the place that had been assigned to me. It is only when we push up against the limits set by the system specific to a space, by being "put back in our 
place," that we become aware of this assigned place (Favret-Saada 2004). It was also by becoming aware of this system that I decoded the codes, understood the rules of the game, and became more flexible. Case in point, I stopped opposing Johel when I let go, which took the form of "allowing" him access to my body. I changed my strategy in order to play the game as established by the system specific to my field research site, in turn disrupting my entire research process. I (unconsciously) accepted to be affected by the location of my study. Specifically, I moved to a new location, which shifted the base of operations for my research, and resulted in significant costs both financially, and for my identity. Upon returning to my fieldwork, it took over a week before I was able to both go out on my own, and convince myself that I had the requisite skills to undertake my research. My identity as a researcher was marked by this event. My pre-field research also impacted by data collection. In order to avoid relying on the help of local males, I developed a new strategy. I joined a community of tourists in the same way as the women I was interviewing had, a group that only shared sexual (or even social) relationships with fellow tourists. In short, this incident affected the entirety of my research since after it, my project no longer resembled the initial one presented earlier in the article.

\section{Criminology, gendered and sexualized bodies}

Sexuality is a taboo subject that has long been a source of curiosity. Indeed, sexuality is a subject of study from medicine to geography, as well as in sociology, anthropology, and education. And yet, sexuality researchers in the field of social sciences and humanities are often stigmatized by bearing in a certain way the prejudices attributed to their participants (de Craene 2017; Tewksbury 2015; Wesely 2015). Thus, studying sexuality attributes erotic subjectivities to researchers, resulting in their being perceived to be more sexually open. Tania Israel (2002) notes, for example, that studying sexualities can result in the researcher being compared to a sex worker. She qualifies this by explaining that the stigma is less severe for female researchers, as carrying out a study on sexuality is considered more "legitimate" than directly partaking in the sexual activity being studied. For individuals (especially women) working in the sex industry, there is often a sense that they are highly judged and not taken seriously whenever the nature of their livelihood is discovered. They live in the anguish of "hiding" their activity so as not to be stigmatized and so that their identity is not reduced to their (generally highly despised) profession. On this point, she highlights that she had a somewhat comparable experience as a researcher, whereby her identity seemed to merge with her research project. She describes how colleagues often introduced her to new acquaintances by following Tania with "she does research 
on strippers," as if it were her last name. She also discusses the extent to which researchers working on subjects related to sexuality make use of the same stigmamanagement strategies employed by sex workers. Her findings and experience, and also shared by Jacqueline Sanchez Taylor and Julia O'Connel Davidson (2010), demonstrates the extent to which sexuality is a malaise-inducing topic, one that leaves no one indifferent to it.

In the field of criminology, sexuality is studied more as a form of deviance. Criminologists will study so-called deviant sexual behaviour (as shown in the DSM-V and its paraphilia list), or crimes with sexual connotations. As a result, a distance is naturally created between the researchers and those being studied. The deviant or even criminal label attributed to participants leads to a stable relationship in the research process. Participants are sexualized from the start, and in return, researchers also expect to be sexualized (Tewksbury 2015). In this case, the reflexive process does not take into account these researchers' sexuality and erotic subjectivities, since they are, to a certain extent, controlled for upstream.

Recognizing that recruited participants have been identified as sexually deviant, researchers will reduce the chances of being sexually objectified by dressing in a neutral and professional manner. As well, they may inquire about their participants' sexual preferences so as to assure that they do not physically match them, prior to conducting an interview (Tewksbury 2015). The study of sexuality in the context of sexual and criminal deviance is also generally carried out in an institutional context (whether carceral or medical). This leaves the impression that professional respect reigns between the various actors partaking in the research, leading to an absence of erotic subjectivities attributed to the researcher's body on the part of their peers.

In fact, as has been shown by Elizabeth Stanko (1992), nothing could be further from the truth, regardless of the chosen research field in criminology. Her study, which reports comments from women either undertaking research or working in police, correctional or legal agencies offer a good example. In relying on a researcher informant, she states: "working in a correctional setting, we were 'expected' to flirt with guards/supervisors. It was normative and a way to get access to data," (Stanko 1992:335).

"All researchers (not just those whose research centres on sex) enter the research field as sexual, gendered, raced, and classed beings, with their real or perceived sexual identity impacting all encounters in the field," (Sanchez Taylor and O'Connel Davidson 2010:51). Positioning oneself as a nonsexualized researcher throughout the research 
and reflexive processes means depriving oneself of the chance to identify either the eroticization of our body by other research actors, or its influence on the production of knowledge. This is in contradiction to the reflexive process advocated for by cultural criminology. Concealing this potential eroticization can also result in the trivialization (or even censoring) of any occurring form of sexual or gendered violence (Hanson and Richards 2019), while also implicitly sustaining the Madonna/wife/whore triad that feminist researchers fight against (Sanchez Taylor and O'Connel Davidson 2010). While we (without a doubt) take into account the fact of having been insulted or attacked because of our ethnicity or social class while undertaking the reflexive process, we must also do the same when it comes to our sexuality in order to produce a truly situated and positioned knowledge.

\section{Conclusion}

The reflexive process rooted in the qualitative methodologies put forward by cultural criminologists is currently incomplete. Firstly, it essentializes, conceals, or denies the sexuality and erotic subjectivities attributed to the bodies of researchers, which raises important methodological and political issues. Secondly, it does not take into account the power relations present in the relationships between the researcher and other research actors, such as gatekeepers. Indeed, the reflexive process maintains that knowledge is co-constructed throughout the research process. It is therefore important that these relationships and the resulting power dynamics be included.

The negation of these two components in the scientific literature is detrimental to the production of a situated and positioned knowledge. It suggests that the researcher is nonsexualized and immune to all forms of eroticization, especially on the part of other research actors. However, the reality is quite different. The researcher's body remains sexualized in the field as it is in everyday life, with the same sexualized body simply transported to a different place and time. Thus, not taking into account the researchers' sexuality is in complete contradiction with the reflexive process so closely associated with fieldwork.

In practice, the ethnographer assigns themself a place in the research field, specifically that of an asexual professional. And yet, ethnography invites us to lose ourselves, to allow ourselves to be assigned a place in a world unknown to us (FavretSaada 2004). The field research site thus becomes a social liminal space, or an inbetween for the ethnographer that can plunge them into a situation of vulnerability. It is by accepting the place attributed to them that the ethnographer can become aware of the vulnerability discussed in this article and act accordingly. 
Thus, the illusion of the nonsexualized and undesired researcher present in the academic literature hinders novice researchers from being adequately prepared. It specifically conceals the reality of a possible eroticization of their body in the research field by actors other than the participants. In so doing, an error in the degree of interpretation of actions that are taken can place ethnographers in vulnerable and dangerous situations, as was the case for myself and other female colleagues.

Thus, it is important to include both the notion of sexuality, and the erotic subjectivities that result from it, in the reflexivity process employed by qualitative methodology within the field criminology. Its inclusion will be beneficial for an improved production of knowledge that is situated and positioned within the discipline, while also highlighting a reality experienced by female ethnographers, namely a form of gendered violence. This also leads to the additional inclusion of the relations of power present between the ethnographer and all other research actors.

\section{Implication}

Lifting the veil on these realities makes it possible to be faithful to the principles of the reflexive process. In addition, by showing that sexuality and the eroticization of bodies are part of the research process, we also highlight a form of gendered violence that has for too long been trivialized. I believe that it is the duty of criminologists to denounce this violence. I therefore invite my fellow criminologists to continue this conversation in their published works, by including the erotic subjectivities of their bodies, as well as their relationships with all those involved in their research.

\section{References}

Affergan, F. (1987), Exotisme et altérité : essai sur les fondements d'une critique de l'anthropologie. Presses universitaires de France.

Beaud, S., and Weber, F. (2010), Guide de l'enquête terrain. La Découverte.

Becker, H. (1963), Outsiders. Studies in the Sociology of Deviance. Free Press of Glencoe.

Bell, D., Caplan, P., and Karim, W. J. (1993), Gendered Fields. Women, Men and Ethnography. Routledge.

Bell, D., and Valentine, G., eds. (1995), Mapping Desire: Geographies of Sexualities. Routledge. 
Bertucci, M.M. (2009), Place de la réflexivité dans les sciences humaines et sociales : quelques jalons, Cahiers de sociolinguistiques, 14/1 : 43--55.

Brougham, P. (2012), 'Risk to Researchers: An Exploration of Issues Experienced by Social Scientists Conducting Research on Social Deviance and Criminal Behavior.

(Ph.D. Thesis). Indiana University of Pennsylvania, USA.

Bucerius, S.M. (2013), 'Becoming a 'Trusted Outsider'. Gender, Ethnicity, and Inequality in Ethnographic Research', Journal of Contemporary Ethnography, 42/6: 690$-721$.

Campbell, R. (2002), Emotionally Involved: The Impact of Researching Rape. Routledge.

Clair, I. (2016), 'La sexualité dans la relation d'enquête. Décryptage d’un tabou méthodologique'. Revue française de sociologie, 57/1 : 45--70.

Clark, I., and Grant, A. (2015), 'Sexuality and Danger in the Field: Starting an Uncomfortable Conversation, Journal of the Anthropological Society of Oxford Online, 8/2: 1--14.

Climo, J. (1999), 'Intimacy and Liminal Space. In F. Markowitz, and M. Ashkenazi, eds., Sex, Sexuality, and the Anthropologist, 43--56. University of Illinois Press.

Cupples, J. (2002), 'The Field as a Landscape of Desires: Sex and Sexuality in Geographical Fieldwork', Area, 34/4:382--390.

de Craene, V. (2017), 'Fucking Geographers! Or the Epistemological Consequences of Neglecting the Lusty Researcher's Body', Gender, Place and Culture, 24/3: 449--464

de Graeve, K., and de Craene, V. (2019), 'The Researcher's Erotic Subjectivities: Epistemological and Ethical Challenges', Documents d'analisi geografica, 65/3: 587601.

Denzin, N.K. (1989), Interpretative Interactionism. SAGE.

Duncan, N. (1996), BodySpace: Destabilising Geographies of Gender and Sexuality. Routledge.

Favret-Saada, J. (2004), 'Glissements de terrain', Vacarme, 3/28: 4--12.

Favret-Saada, J. (2009), Désorceler. Les Éditions de l’Olivier. 
Ferrell, J., and Hamm, M. eds. (1998), 'True Confession. Crime, Deviance, and Field Research', in Ethnography at the Edge: Crime, Deviance and Field Research, 2--19. Northeastern University Press.

Fitz-Gibbon, K. (2017), ‘Gaining Access and Managing Gatekeepers: Undertaking Criminological Research with Those 'Within' the System' in M. Hviid Jacobsen, and S. Walklate, eds., Liquid Criminology: Doing Imaginative Criminological Research, 173-187. Routledge.

Frohlick, S. (2013), 'Sexuality, women and tourism. Cross-border desires through contemporary novel. Routledge.

Frohlick, S., and Harrison, J. (2008), 'Engaging Ethnography in Tourist

Research. An introduction', Tourist Studies, 8/1: 5--18.

Geertz, C. (1998), 'La description dense. Vers une théorie interprétative de la culture', Enquête, 6 : 73--105.

Gelsthorpe, L. and, Moriss, A. eds. (1990), Feminist Perspectives in Criminology. Open University Press.

Hanson, R. and, Richards, P. (2019), Harassed: Gender, Bodies, and Ethnographic Research. University of California Press.

Harding, S. G. (1991), Whose Science? Whose Knowledge? Cornell University Press.

Hayward, K. (2016), 'Cultural Criminology: Scripts Rewrites', Theoretical Criminology, 20/3: 297--321.

Hayward, K., and Young, J. (2004), 'Cultural Criminology; Some Notes on the Script', Theoretical Criminology, 8/3: 259--273.

Hert, P. (2014), 'Le corps du savoir : qualifier le savoir incarné du terrain', Études des communication, 42, 29--46.

Israel, T. (2002), 'Studying Sexuality: Strategies for Surviving Stigma', Feminism \& Psychology, 12/2: 256--260.

Jacobs, J. (2009), 'Have Sex Will Travel: Romantic 'Sex Tourism' and Women Negotiating Modernity in the Sinai', Gender, Place and Culture, 16/1: 43--61. 
Jewkes, Y. (2012). 'Autoethnography and Emotion as Intellectual Resources: Doing Prison Research Differently', Qualitative inquiry, 18/1: 63--75.

Kane, S. (2004), 'The unconventional methods of cultural criminology', Theoretical Criminology, 8/3: 303-321.

Kleinman, S. (1991), 'Field-Workers' Feelings: What We Feel, Who We Are, How We Analyze', in W. B. Shaffir, and R. A. Stebbins eds., Experiencing Fieldwork: An Inside View of Qualitative Research,184--195. SAGE Focus Edition.

Kloß, S. T. (2017), 'Sexual(ized) Harassment and Ethnographic Fieldwork: A Silenced Aspect of Social Research. Ethnography, 18/3:396--414.

Kulick, D., and Wilson, M. eds. (1995), Taboo: sex, identity and erotic subjectivity in anthropological fieldwork. Routledge.

Lee, R. ed. (1995), Dangerous fieldwork. SAGE.

Lee-Treweek, G., and Linkogle, S. eds. (2002), Danger in the Field. Risk and Ethics in Social Research. Routledge.

Lévi-Strauss, C. (1968), 'Introduction à l'œuvre de Marcel Mauss', in M. Mauss ed., Sociologie et anthropologie, IX--LII. Presses universitaires de France.

Lyng, S. (2014), 'Action and Edgework: Risk Taking and Reflexivity in Late Modernity', European Journal of Social Theory, 17/4: 443--460.

Monaghan, L. (2011)., 'Fieldwork and the Body. Reflections on an Embodied Ethnography', in D. Hobbs, and R. Wright eds., The SAGE Handbook of Fieldwork, 226-241. SAGE.

Moreno, E. (1995), 'Rape in the Field', in D. Kulick, and M. Wilson eds., Taboo. Sex, Identity and Erotic Subjectivity in Anthropological Fieldwork, 219--250. Routledge.

Panfil, V., and Miler, J. M. (2015), 'Feminist and Queer Perspectives on Qualitative Methods', in H. Copes et J. M. Miller eds., The Routledge Handbook of Qualitative Criminology, 34--43. Routledge.

Plump, B. and, Geist-Martin, P. (2013), 'Collaborative Sexuality: Negotiating Identity, Liminal Spaces, and Ethnographic Research', Liminalities: A Journal of Performance Studies, 9/2: 59--72. 
Ponterotto, J. G. (2006), 'Brief Note of the Origins, Evolution, and Meaning of the Qualitative Research Concept “Thick Description”', The Qualitative Report, 11/3: 538-549 .

Poupart, J. (2011), 'Tradition de Chicago et interactionnisme : des méthodes qualitatives à la sociologie de la déviance', Recherches qualitatives, 30/1 : 178--199.

Root, C., Ferrell, J. and Palacios, W.R. (2013), 'Brutal Serendipity: Criminological Verstehen and Victimization', Critical criminology, 21/2:141-155.

Rose, G. (1997), 'Situating Knowledges: Positionality, Reflexivities and Other Tactics', Progress in Human Geography, 21/3: 305--320.

Ross, K. (2013), “No Sir, She Was Not a Fool in the Field”: Gendered Risks and Sexual Violence in Immersed Cross-Cultural Fieldwork', The Professional Geographer, 67/2: 180--186

Rowbotham, S. (1973), Women's Consciousness, Men's World. Pelican books.

Sanchez Taylor, J. and O’Connel Davidson, J. (2010), 'Unknowable Secrets and the Golden Silence', in R. Ryan-Flood, and R. Gill eds., Secrecy and Silence in the Research Process. Feminist Reflection, 42--53. Routledge.

Stanko, E. (1992), 'Intimidating Education: Sexual Harassment in Criminology', Journal of Criminal Justice Education, 3/2: 331--340.

Tewksbury, R. (2015), 'Using Qualitative Methods to Study Sex Crime', in H. Copes, and J. M. Miller eds., The Routledge Handbook of Qualitative Criminology, 204--214. Routledge.

Turner, V. (1979), 'Frame, Flow and Reflection: Ritual and Drama as Public Liminality, Japanese Journal of Religious Studies, 6/4: 465--499.

Wakeman, S. (2014), 'Fieldwork, Biography and Emotion: Doing Criminological Autoethnography', British Journal of Criminology, 54/5: 705--721.

Wesely, J. K. (2015), 'Negotiating Identity as a Qualitative Researcher', in H. Copes, and J. M. Miller eds., The Routledge Handbook of Qualitative Criminology, 144--155. Routledge.

Young, J., and Brotherton, D. (2014), 'Cultural Criminology and Its Practices: A Dialog Between Theorist and the Street Researcher', Dialectical Anthropology, 38/2: 117--132. 


\section{Footnotes}

1. This name is a pseudonym. The purpose of this article is not to denounce my aggressor, but rather to reveal the way in which denying researchers' erotic subjectivities can indirectly result in such an incident. Nonetheless, I view this sharing as a political gesture. $\_$ 